\title{
Appraisal of Public Perception of Lagos State Domestic Violence Policy
}

\author{
Oluwadele, L. Bolutife ${ }^{1}$, Okaiyeto, Simon Ayodele ${ }^{2}$ Olaogun, Michael Sunkanmi ${ }^{3}$ \\ ${ }^{1}$ Doctoral Candidate, Public Policy and Administration, Walden University, USA \\ ${ }^{2}$ Mass Communication Department, Salem University, Lokoja, Nigeria. \\ ${ }^{3}$ Pan Africa Youth Democracy Fellow, Policy Analyst, Abuja, Nigeria \\ DOI - http://doi.org/10.37502/IJSMR.2021.4509
}

\begin{abstract}
The paucity of specific laws and policies to address domestic violence against women in Nigeria is palpable. The issue is further complicated by the inadequacy of the penal codes that have been used in most cases to substitute for the apparent lapses. Some states in the country have risen to the occasion of addressing this issue. Amongst such states is the metropolitan Lagos state who enacted a law on domestic violence and backed it up with a policy that focuses on the effect of domestic violence on children. In addition, the State has set up an agency that caters to the needs of the victims of domestic violence that report occurrence(s). While this is a laudable step by the Lagos government, this study revealed that the level of awareness is still incredibly low. Second, a substantial number of respondents still hold the cultural inclination to reporting incidences of domestic violence to their spiritual leaders more than not to report the same to the agency. Therefore, we call the Lagos Government to consider a policy review to make it more encompassing than focusing on the children. Second, we advocate for more stakeholders' engagement in the event of such consideration.
\end{abstract}

Keywords: Domestic violence, Lagos state, policy, awareness, agency, spiritual leaders.

\section{Introduction}

Because of the inadequacy of laws and regulations to take care of unabated domestic violence in Nigeria (Madu, 2015), partly due to the insufficiency of penal codes, which does not explicitly address the issue of domestic violence, and the pressure for social change (Walden University. n.d) through social media, the Lagos State, Nigeria came with a policy on domestic violence. The Policy, "Lagos State Safeguarding and Child Protection Policy" (Domestic Sexual and Violence Response Team. n.d.), is considered inadequate because it is not addressing women as part of domestic violence victims. While there is a universal affirmation that women (Madu, 2015) are the primary victims of domestic violence, it is considered a policy formulation oversight. It becomes a problem on its own when the main components of whom the policy should address are conspicuously left out. The policy's problem can be addressed if the public and most especially stakeholders in the society are carried along all through the designing of the policy. It is essential to know the level of public knowledge with respect to the policy. 
Domestic violence is a public policy concern, as it involves a societal problem. Virkki (2017) stated that "It is, therefore, crucial to consider policies not, simply, as responses to problems that exist "out there" in society, waiting to be solved through policy interventions, but rather as competing interpretations of given problem areas" (p.2). Therefore, there is the need to investigate the public perception of the Lagos state Domestic violence policy, hence asking the research question.

\section{The Research Question Rationale.}

Research Questions

1. What is the rate of domestic violence in Lagos state?

2. What is the level of public knowledge of Lagos state domestic violence policy?

3. Has the policy neglected women who are regarded as significant victims of domestic violence?

4. What are the areas to be considered to improve the policy to be effective in addressing domestic violence?

\section{Literature Review}

Domestic violence, though it may differ in contents and characteristics, from place to place, there is no doubt that it is a global problem (Madu, 2015; McQuigg, 2018). Discussing the import of its universal nature, Cejvanovic et al. (2015: 544) indicated that:

Violence against women represents a serious social problem, and it reflects through the gender-sex discrimination of women (Antić, 2000). One form of the violence against women is domestic violence. Reports of the World Health Organization (WHO, 1996) show that domestic violence is widespread, and it demands a comprehensive answer from all states". (p.544)

Despite its universality, slight variations also exist about what constitutes domestic violence. Some definitions are all-encompassing, while others created some distinctions between domestic violence and sexual violence on the one hand, and the other Intimate Partner Violence (IPV), as a variant of domestic violence. For Madu (2015), domestic violence is allencompassing in that all acts of violence against women, physical, emotional, cultural, social, and all discrimination against women are regarded as domestic violence. He, Madu (2015) is supported by Cejvanovic et al. (2015) and others like Metz et al. (2018). Though Metz et al. (2018) use the term "marital violence" (p.4) also to qualify domestic violence, it did not show any significant variation from the other literature referred to earlier. Whereas McCauley, Head, Lambert, Zafar, and van den Broek (2017) were more contented to term it as violence against women, with able allies in Badea (2018) and Menjivar and Walsh (2017), others such as Leclerc et al. (2016), simply called sexual violence against women. For Tabassum et al. (2015), it is regarded as a crime against women. On another level, Gage and Thomas (2017) addressed from the angle of intimate partner violence (IPV). This position was also seen in Zulfiqar (2017) and Kim (2017) in their discussions on marital rape in Pakistan and India, respectively. Despite what may be termed differences in terminologies, as espoused by various authors from Sweden (Helmersson \& Jonson, 2015), Brazil (Rodrigues et al. 2017), Romania (Badea, 2017), 
United Kingdom (Bowstead, 2015), Honduras (Menjivar \& Walsh, 2017), Pakistan (Zulfiqar, 2017), Nigeria (Madu, 2015; Gage \& Thomas, 2017; Nwabunike \& Tenkorang, 2015), and many diverse others, two things are clear and common with all, violence and women. In giving a broad categorization of domestic violence against women, Madu (2015: 280) attempted an all-encompassing definition as

Hence, domestic violence or intimate partner violence (IPV) may be categorized as physical violence, sexual violence, psychological (emotional) abuse, and controlling

behaviors. Physical violence entails hitting with a fist, pulling hair, slapping, kicking, pushing, grabbing, threatening with, or attacking someone with any weapon, etc. Sexual violence involves forced sexual intercourse (rape), sexual harassment, and other forms of sexual abuse. Psychological or emotional abuse includes insults, discrimination, intimidation, threats, etc. Controlling behaviors include, among others, stalking, depriving one the right of association and the restriction or denial of economic, educational and healthcare opportunities" (p.280)

Given this broad view about what constitutes domestic violence against women, with supports across the literature (McQuigg, 2018; Odion \& Eboigbe, 2018; Grans, 2018), it thus called for attention that the "Lagos State Safeguarding and Child Protection Policy" (Domestic Sexual and Violence Response Team. n.d.), choose to focus on child protection as the center of its domestic violence. The concerns led to the topic of this review, which.

is 'appraisal of public perception of Lagos state domestic violence policy.' An attempt to do such an evaluation will trigger some questions as the basis of the inquiry. The first item for such evaluation will be 'How and why does the domestic violence policy of Lagos State, Nigeria exclude women, but focus on children as victims alone?

To do the appraisal, a critical look at what constitutes domestic violence will be followed by its effects on women across some jurisdictions to give it as much disperse as possible. Then, some attempt will be made about how the perennial occurrences of domestic violence are being tackled, again in some places, after which an evaluation of the policy enacted by Lagos State Nigeria in this regard will be made and possible recommendations on how, if it needs to, be remedied. In doing this review, the authors will utilize a quantitative research approach.

\section{Elements of Domestic Violence}

As earlier stated, various authors described domestic violence in various ways, even though there seemed to be a commonality in terms of violence and women. For instance, Bishwajit and Yaya (2018) used various terminologies to describe it as gender discrimination, intimate partner violence (IPV), or abuse and asserted that both men and women could become victims. Nevertheless, quoting consciously from the World Health Organization (WHO), they, Bishwajit and Yaya (2018) affirmed that domestic violence is "the range of sexually, psychologically and physically coercive acts used against adult and adolescent women by a current or former male partner" (p.22). Subscribing to the definition provided by the WHO, Bishwajit and Yaya (2018) contradicted themselves in saying that men and women can both be victims of domestic violence. The position taken here is akin to what McQuigg (2017) called gender neutrality to avoid the possibility of overemphasizing women in terms of domestic 
violence as discrimination against men. To demonstrate the significance of gender neutrality and how it can hinder the understanding of what needed to curb it against women, McQuigg (2017) quoted from the U.N. General Assembly report:

"The concept of gender neutrality is framed in a way that understands violence as a threat to which all are potentially vulnerable and from which all deserve protection. This suggests that male victims of violence require, and deserve, comparable resources to those afforded to female victims, thereby ignoring the reality that violence against men does not occur as a result of pervasive inequality and discrimination, and also that it is neither systemic nor pandemic in the way that violence against women indisputably is." (p.314)

Contextually speaking. Therefore, domestic violence should be broadly viewed from "both criminal offenses and cultural practices resulting in the victimization of women" (Tabassum et al., 2015, p.16). Addressing the elements of domestic violence, especially in Nigeria, Odion and Eboigbe (2018) were even more pedestrian. Odion and Eboigbe (2018) categorized it into five elements: physical abuse, sexual violence, psychological abuse, emotional violence, and economic violence (p.934-935). In addition, they provided some breakdown as:

"the most common form of violence is wife battery, ranging from beating, slapping or kicking to verbal abuse, punishment, eviction from the home, denial of financial resources, rape, maiming, and death... Failure to prepare tasty meals or not preparing meals on time, talking to her husband disrespectfully, arguing with her husband, being disobedient to her husband, or refusing sex when it is demanded by her husband, or being under suspicion of having an extramarital affair or being disrespectful to her inlaws are among some of the many reasons for domestic violence" (Odion \& Eboigbe, 2018, p.935)

As ridiculous as these reasons may sound, its perpetuation found strength and encouragement in some age-long cultures and traditions (Nwabunike \& Tenkorang, 2017; Zulfiqar, 2017; Rodrigues et al. 2017; Kim, 2017; Metz et al. 2018; McCauley et al., 2017; Menjívar et al. 2017; Bishwajit \& Yaya, 2018; Khan, 2015). Situating these abysmal cultural practices within the social construct, Tabassum et al. (2015) stated that "The social structure of the social institutions in society conditions its overall functioning and the status of different groups of people living within it. The social structure of Pakistani society is based on patriarchy (Shaheed 1991, 135-158). In this patriarchal nature of society, men dominate women in most aspects of social life (Johnson 1997, 5; Millett 1970, 25). Therefore, women in Pakistan face discrimination at all levels of the social life." (p.17). These situations are almost similar in many countries where women still suffer significant discrimination in most spheres of life. Menjívar and Walsh (2017) extended it further to include all kinds of marginalization, vulnerabilities, brutalities, and all forms of inequalities suffer by women as distinct from their male counterparts in the Honduran society. Therefore, all types of depravations that are gendered inclined can be categorized as constituting the elements of domestic violence against women. To further emphasized the untoward consequences of these elements, Menjívar and 
Walsh (2017) stated that "While we expose women's poverty-related vulnerabilities, our approach moves beyond income disparities to highlight inequalities in citizenship rights where the State is a key player in perpetuating and reinforcing unequal access to justice and rights. We point to the confluence of factors that facilitate violent conditions for women that can ultimately culminate in their killings. In doing so, we reveal processes by which structural inequality translates into unequal access to safety and justice for Honduran women." (p.222). The profound statement above obviously finds expression and validity within the five categories as espoused by Odion and Eboigbe (2018), stated earlier. It goes beyond inflicting bodily injuries on the victims, as souls and the victims' spirits feel the weight of sometimes structural inequalities that they are forced to bear.

\section{Women as most victims}

Though there may seem to be some sense in the gender neutrality approach (McQuigg, 2017), it is overwhelmingly agreed in the literature that women suffer most from the consequences of domestic violence. Following one of the weightiest assertions in this regard is the claim made by Cejvanovic et al. (2015: 543) that:

"Research results show that victims of domestic violence are in $90 \%$ of the cases women (wives, mothers, daughters, sisters, etc.) and that domestic violence is constantly increasing each following year. All forms of violence over women come stem from a principal discrimination towards women, which results in coerce or use of force. For that reason, violence over women is a manifestation of a fundamentally unequal position of women and men, and it represents a form of discrimination against women" (p.543).

With this kind of information, the gender neutrality approach becomes a complete disservice to the knowledge and treatment of domestic violence. This kind of statistics also challenges us, as global citizens, not to downplay the devastating effects of domestic violence by claiming it can happen to anyone. It may be true that there are instances where men can be victims of domestic violence, but that will still be incomparable with women who suffer $90 \%$ of the time. In another confirmation of sort, Nwabunike and Tenkorang (2015) claimed that nearly twothirds of women experience domestic violence from their male partners. Of course, this is not accounting for unmarried women, rape against adolescent girls, widows (Rodrigues et al. 2017; Kim, 2018; Gage \& Thomas, 2017; Fakunmoju \& Rasool, 2018). Also collaborating on this phenomenon, Metz et al. (2018) affirmed that a quarter of women in the United States experience domestic violence at one time or the other. It is also disheartening that often the violence results in the untimely death of the victims. Expanding further on their assertions, Metz et al. (2018) informed that as high as 1200 women died from domestic violence in the United States, while in France, one woman died every three days due to domestic abuse (Metz et al. 2018, p.1). Khan (2015), thinking about this striking statistic, concluded that "[V]iolence against women is perhaps the most pervasive form of abuse, a universal phenomenon that transcends divisions of class, race, religion, ethnicity, and geography." (p.210, citing Pickup, William \& Sweetman, 2001). It appeals to sense and good judgment; therefore, that any domestic violence remediation that overlooks this fact can only be sub-optimal in the least and 
outrightly wicked in its profundity. Beyond its recognition as a global problem (Leclerc et al. 2016), its 'staying' power requires equal probing if any desire for a plausible solution is ever envisaged. Therefore, in the context of the above statement, the next logical question is: What is the holding power of domestic violence that supports its unbridled pervasiveness? How well can all the supporting pillars pull down to allow for effective remediation in the short term and elimination in the long term?

Though, Solanke et al. (2018), in their survey of the impact of domestic violence among childless women, indicated that an affirmative conclusion was challenging, nevertheless "[T]he psychological and social consequences associated with childlessness include but not limited to marital conflict, psychiatric morbidity, psychological distress, sexual dysfunction, and spousal violence" (p.2). , it can thus be inferred that it is not the fertility of a woman alone that exposes or immune her from violence.

\section{Supporting Pillars of Domestic Violence}

Why is domestic violence thriving despite the unfavorable reviews of the same in the literature? Why is no society excluded from its devastating occurrences and consequences? Madu (2015) let us know that the most reliable pillar, perhaps supporting this heinous crime against 'half' of humanity, is "the patriarchal nature of many societies (that) supports the dominance of men in almost all affairs; women still face injustice and violence in these societies, constituting obstacles to the realization of their potential as they suffer low selfesteem, depression, anxiety and, at times, post-traumatic stress disorder for being so treated" (p.279). This position found empirical support in the literature (Kim, 2018; Zulfiqar, 2017; Nwabunike \& Tenkorang, 2017; Odion \& Eboigbe, 2018; Metz et al. 2018; McCauley et al., 2017; Menjívar et al., 2017), which variously reported patriarchy as one of the primary enablers of domestic violence in many societies across the globe.

Beyond patriarchy as a phenomenon, are cultures embedded in religions, traditions, and even states complicity (Menjívar et al., 2017). Metz et al. (2018), let us know:

"Domestic violence may be understood as the possible trace of the mainly patriarchal organization of societies, inducing hierarchical gender relations between men and women throughout the world (Aisenstein, 2006; Istanbul Convention, 20113; Jukes, 1993). For Stein (2014), "Women's passivity was largely supported by family, community, church, law, and medicine, cultural institutions that promote and police binary gender roles" (Chapter 1). The cultural and social factors involved in marital violence are multiple and well-identified. According to the World Health Organization (2016): "Factors associated with increased risk of experiencing intimate partner and sexual violence include low education, exposure to violence between parents, abuse during childhood, attitudes accepting violence and gender inequality." (p.1)

For instance, in places like Brazil, lifestyles such as alcoholism, drugs abuse, and illegal weapon possession contribute to widespread domestic violence (Rodrigues et al., 2017). Whereas, in India (Kim, 2018), Pakistan (Zulfiqar, 2017; Tabassum et al., 2015), Bangladesh (Khan, 2015), culture and religions play a tremendous supporting role in domestic violence perpetration. Even in a seemingly plural society like Nigeria (Nwabunike \& Tenkorang, 2017; 
Bishwajit \& Yaya, 2018), three dominant ethnicities are enablers despite some variations, cultural practices across the country as well. Also, in South Africa (Fakunmoju \& Rasool, 2018), patriarchy and cultures found common ground in sustaining the phenomenon. Even in countries like U.K. (Bowstead, 2015), Romanian (Badea, 2017), Bosnia and Herzegovina (Cejvanovic et al. 2015), Sweden (Helmersson \& Jonson, 2015), where patriarchy may not be well pronounced, gender inequalities through practices help in no small measure in strengthening the cords that make it challenging to unwind domestic violence in the polity. If these enablers are not existing or have been removed, perhaps, we will today be studying domestic violence as mere historic relics of the dark ages. However, being active and alive, we are constrained to have a more than cursory look at these issues as we move towards the enormous ambition of eliminating domestic violence across the globe. To have such a goal may mean that we have come to appreciate the consequences of allowing it to thrive. Therefore, we will next consider, in brief, the damning implications of domestic violence in our world.

\section{Effects of Domestic Violence on Women}

While the overall effects of domestic violence literally on society are not sound, they are worse on women who bear the most brunt. Despite the underreporting (Leclerc et al. 2016) of its occurrence due to stigma and other cultural barriers (McCauley et al. 2017), the victims suffering includes amongst others "murder, kidnapping, rape, gang rape, and (others) (Tabassum et al. 2015, p.17). McCauley et al. (2017) went a little further to elaborate on other consequences:

"Domestic violence during pregnancy is associated with poor health outcomes for both the woman and her unborn baby including maternal injury or death; and pregnancy complications such as placental abruption, premature rupture of membranes, preterm labor, low birth weight, and stillbirth. Domestic violence also has life-long negative implications for a woman's general health, including physical (chronic pain, migraines) and psychological (anxiety, depression, post-traumatic stress disorder) consequences. Repeated health care attendance for non-related reasons commonly occurs where a woman is experiencing domestic violence" (p.2)

The situation is not materially different in periods of arms conflict where horrific injuries are inflicted on all civilians, but more on the women folks. (Aoláin, O'Rourke \& Swaine, 2015). Even in the course of post-conflicts, where reparations and other forms of compensations are due to victims (Aoláin et al. 2015), they are most often "excluded from processes of Disarming, Demilitarization, and Reintegration (DDR)" (Aoláin et al. 2015, p.105), when their contributions would have helped in the healing process. In a similar vein, Fakunmoju and Rasool (2018) explained how cultural practices such as bride price payment trap women in unhealthy relationships. Even more annoying is the denial of a woman in the inherence of her parents once she is married (Fakunmoju \& Rasool, 2015). Again Madu (2015) waded in by giving us a snapshot of consequences as "physical, psychological and intellectual, health, socio-economic, and the inability of women to reach their potential" (p.281). Most of these were collaborated by Khan (2015) in his discourse on the consequences in rural Bangladesh communities and Nwabunike and Tenkorang (2017), among Nigerian ethnic 
groups. Metz et al. (2018) also discussed the unfair treatment of women and their inability even to opt-out.

\section{Methodology}

To answer the research questions, a combination of primary and secondary sources of data was used. A survey method through a structured questionnaire was used to gather the public's views regarding the Lagos state domestic violence policy. Questionnaires were administered to some select groups, such as students, who may have had some intimate experience in domestic violence and are not part of those identified as a group or visible individuals such as elected officials, government officials, nonprofit organizations, and other groups that may be defined like advocacy groups. Secondary sources: information from the secondary sources was sourced from multiple databases. Such will include government databases, research organizations that have carried out previous works on domestic violence, related policy, advocacy groups databases, university databases, and other academic journal databases. The data collected from the secondary sources were reviewed through meta-analysis techniques.

\section{Findings}

Two hundred and fifty-six (256) respondents' data were collected with a google form questionnaire via online means. SPSS version 21.0 was used for the analysis. The demography data shows that $63.3 \%$ of the respondents are females, while $36.7 \%$ are males. Since the focus of the study is respondents who reside in Lagos who have experience on gender and domestic violence and respondents who have 18 years and above data utilized. Consequently, the majority $98.8 \%$ ) of the respondents fall within the age bracket of 18 years and above. Also, 53.1\% experienced or knew someone close that have experienced domestic violence in Lagos state. While $89.1 \%$ have a story about someone that has experienced domestic violence in Lagos state.

Table 1: Rate of Domestic Violence in Lagos

\begin{tabular}{lll}
\hline $\begin{array}{l}\text { Do you Agree that Domestic Violence is Common } \\
\text { in Lagos state }\end{array}$ & Frequency & Percentage (\%) \\
\hline Strongly Disagree & 1 & .4 \\
Disagree & 7 & 2.7 \\
Neutral & 25 & 9.8 \\
Agree & 132 & 51.6 \\
Strongly Agree & 91 & 35.5 \\
Total & $\mathbf{2 5 6}$ & $\mathbf{1 0 0 . 0}$ \\
\hline
\end{tabular}

Source: The Researchers, 2021

Over three quarter $(87.1 \%)$ of the respondents agree that domestic violence is common in Lagos. This means that victims of domestic violence have not yet seen the positive effect of government policies on gender and domestic violence. 
159 | International Journal of Scientific and Management Research 4(5) 151-165

Table 2: Awareness on the State Policy on Domestic Violence

\begin{tabular}{llll}
\hline $\begin{array}{l}\text { Awareness on the State Policy on Domestic } \\
\text { Violence }\end{array}$ & Frequency & Percentage (\%) \\
\hline No & 117 & 45.7 \\
Yes & 139 & 54.3 \\
Total & $\mathbf{2 5 6}$ & $\mathbf{1 0 0 . 0}$ \\
\hline
\end{tabular}

Source: The Researchers, 2021

Over about half $(54.3 \%)$ of the respondents are aware of Lagos state policy on domestic violence. However, $45.7 \%$ of the respondents are not aware of any state policy regarding domestic violence. This is a pointer that the policy is not exceedingly popular among the public.

Table 3: The Extent Domestic Violence affects lives in the State.

\begin{tabular}{lll}
\hline $\begin{array}{l}\text { The Extent Domestic Violence affects lives in the } \\
\text { State }\end{array}$ & Frequency & Percentage (\%) \\
\hline Little or no Extent & 6 & 2.3 \\
Some Extent & 31 & 12.1 \\
Moderate Extent & 39 & 15.2 \\
Great Extant & 114 & 44.5 \\
Very Great Extent & 66 & 25.8 \\
Total & $\mathbf{2 5 6}$ & $\mathbf{1 0 0 . 0}$ \\
\hline
\end{tabular}

Source: The Researchers, 2021

About three quarter (75\%) agreed that domestic violence affects peoples' lives in Lagos. This means the prevailing rate of domestic violence in the State is taking a toll on people's lives.

Table 4: The Group that is Most Affected by Domestic Violence

\begin{tabular}{lll}
\hline Group Most Affected by Domestic Violence & Frequency & Percentage (\%) \\
\hline Children & 72 & 28.1 \\
Children and Women & 72 & 27.3 \\
Women & 101 & 39.5 \\
Men & 4 & 1.6 \\
Children and Men & 7 & 2.7 \\
Total & $\mathbf{2 5 6}$ & $\mathbf{1 0 0 . 0}$ \\
\hline
\end{tabular}

Source: The Researchers, 2021

The data shows that women and children (96.0\%) are the most affected by domestic violence, and specifically, women (39.5\%) are mostly affected. This shows the imperative of policy that will categorically address women's domestic challenges.

Table 5: Whether the State Domestic Violence Policy should address all Possible Victims irrespective of gender. 


\begin{tabular}{lll}
\hline Variable & Frequency & Percentage (\%) \\
\hline No & 5 & 2.0 \\
Yes & 242 & 94.5 \\
May be & 9 & 3.5 \\
Total & $\mathbf{2 5 6}$ & $\mathbf{1 0 0 . 0}$ \\
\hline
\end{tabular}

Source: The Researchers, 2021

Almost all (94.5\%) agreed that domestic violence policy should address all possible victims irrespective of gender.

Table 6: Whether Domestic Violence is not good for the Society.

\begin{tabular}{lll}
\hline Domestic Violence is not good for the Society & Frequency & Percentage (\%) \\
\hline Strongly Disagree & Nil & 0.0 \\
Disagree & Nil & 0.0 \\
Neutral & 4 & 1.6 \\
Agree & 2 & .8 \\
Strongly Agree & 250 & 97.7 \\
Total & $\mathbf{2 5 6}$ & $\mathbf{1 0 0 . 0}$ \\
\hline
\end{tabular}

Source: The Researchers, 2021

Almost all the respondents agreed that domestic violence is not good for society. Domestic violence has grievous consequences to the home and society at large.

Table 7: Whether Children Suffer the most when there is Domestic Violence.

\begin{tabular}{lll}
\hline $\begin{array}{l}\text { Children Suffer the Most When there is Domestic } \\
\text { Violence }\end{array}$ & Frequency & Percentage (\%) \\
\hline Strongly Disagree & Nil & Nil \\
Neither agree nor Disagree & 2 & .8 \\
Slightly Agree & 10 & 3.9 \\
Moderately Agree & 25 & 9.8 \\
Strongly Agree & 219 & 85.5 \\
Total & $\mathbf{2 5 6}$ & $\mathbf{1 0 0 . 0}$ \\
\hline
\end{tabular}

Source: The Researchers, 2021

Most respondents $(85.5 \%)$ Strongly agree that children suffered the most when there is domestic.

Table 8: Whether Respondents will Report Domestic Violence case to Appropriate Government Agency.

\begin{tabular}{lll}
\hline Report Case of Domestic Violence & Frequency & Percentage (\%) \\
\hline Most Unlikely & 2 & .8 \\
Not Likely & 9 & 3.5 \\
\hline
\end{tabular}


161 | International Journal of Scientific and Management Research 4(5) 151-165

\begin{tabular}{lll}
\hline Not Sure & 2 & .8 \\
Neutral & 12 & 4.7 \\
Likely & 40 & 15.6 \\
Most Likely & 125 & 48.9 \\
Definitely Likely & 65 & 25.4 \\
Total & $\mathbf{2 5 6}$ & $\mathbf{1 0 0 . 0}$ \\
\hline
\end{tabular}

Source: The Researchers, 2021

Most respondents (48.9\%) will most likely report any case of domestic violence to the appropriate government agency. The public has trust in constituted authorities that are saddle with the responsibility of addressing domestic violence issues.

Table 9: Whether Spiritual Leaders Can Solve Domestic Violence

\begin{tabular}{lll}
\hline Spiritual Leaders in Solving Domestic Violence & Frequency & Percentage $(\boldsymbol{\%})$ \\
\hline Strongly Disagree & 19 & 7.4 \\
Slightly Disagree & 8 & 3.1 \\
Somewhat Disagree & 9 & 3.5 \\
Neither Agree nor Disagree & 36 & 14.1 \\
No Opinion & 8 & 3.1 \\
Slightly Agree & 71 & 27.7 \\
Moderately Agree & 59 & 23.0 \\
Strongly Agree & 39 & 15.2 \\
Total & $\mathbf{2 5 6}$ & $\mathbf{1 0 0 . 0}$ \\
\hline
\end{tabular}

Source: The Researchers, 2021

Most respondents (60\%) agree that spiritual leaders have a role to play in solving domestic violence in the State.

Table 10: Whether Families are Aware of the Agency to Report Domestic Violence

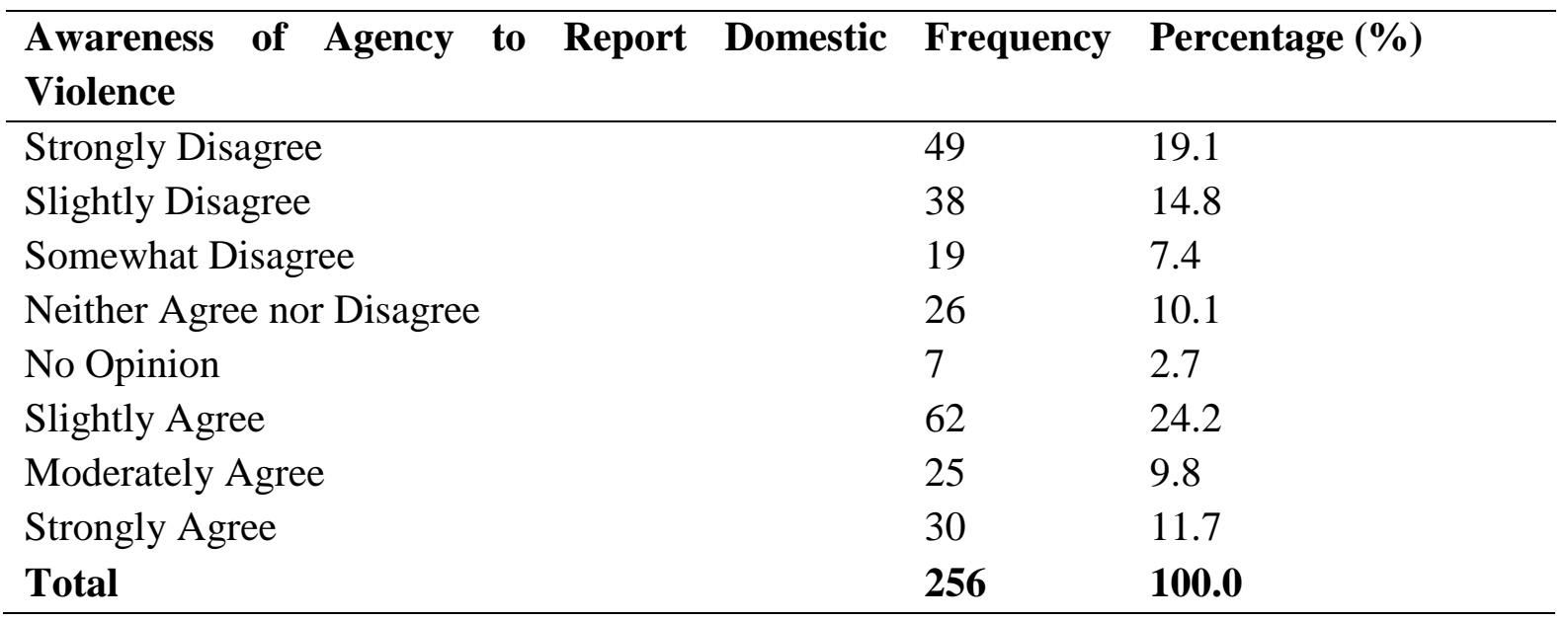

Source: The Researchers, 2021 
About $40 \%$ of respondents agreed that families are not aware of the agency to report violence cases in the State. Thus, the government needs to intensify its campaign on sensitizing the public on domestic violence and the necessary agency responsible for addressing such cases.

\section{Discussion}

The study found that domestic violence is common in Lagos state, thus requiring an active policy to address it. The data shows that victims of domestic violence have not yet seen the significant effect of government policies on gender and domestic violence. Furthermore, the public has limited awareness of the policy's role in addressing domestic violence that women faced. Thus, the government needs to intensify its campaign on sensitizing the public on domestic violence and the necessary agency responsible for addressing such cases.

Though, the public has trust in constituted authorities that are saddle with addressing domestic violence issues.

The prevailing rate of domestic violence in the State is taking a toll on people's lives. The data shows that women and children (96.0\%) are the most affected by domestic violence, and specifically, women (39.5\%) are mostly affected. This shows the imperative of policy that will categorically address women's domestic challenges. Most respondents (48.9\%) will most likely report any case of domestic violence to the appropriate government agency. The public has trust in constituted authorities that are saddle with the responsibility of addressing domestic violence issues. Also, stakeholders in the society, such as spiritual and traditional leaders, have a role to play in addressing domestic violence, and their contribution is necessary for policy implementation.

\section{Conclusion and Recommendations}

The domestic violence policy of Lagos State, Nigeria, has downplayed women but focuses on children as victims alone, and it does not contribute enough to solving domestic violence in the State. There is an urgent need to review the domestic violence policy to include all victims of domestic violence in society. The overall effects of domestic violence literally on society are not sound, and they are worse on women who bear the most brunt of it. Despite the underreporting of its occurrence due to stigma and other cultural barriers, the victims' suffering includes "murder, kidnapping, rape, gang rape, and others. Lagos state agency for addressing domestic violence needs to be apt. The surging rate of domestic violence and its adverse effect on society demands urgent review of the policy to meet up with the present realities. Stakeholders in the society from the traditional and spiritual circle are well trusted and respected by the public; as such, their opinion matters in any policy formulated concerning domestic issues.

\section{References}

1) Aoláin, F. N., O'Rourke, C., \& Swaine, A. (2015). Transforming Reparations for Conflict-Related Sexual Violence: Principles and Practice. Harvard Human Rights Journal, 28(1), 97-146. Retrieved from Walden Library databases. 
2) Baskerville, R. L., Kaul, M., \& Storey, V. C. (2015). Genres of Inquiry in DesignScience Research: Justification and Evaluation of Knowledge Production. MIS Quarterly, 39(3), 541-A9. Retrieved from the Walden Library databases

3) Bishwajit. G., Yaya. S., (2018), Domestic violence: a hidden barrier to contraceptive use among women in Nigeria: Open Access Journal of Contraception (9) 21-28. Retrieved from Walden Library databases.

4) BADEA, C. (2017). Gender-Based Violence: The Romanian Public Agenda and its Missing Points. Sphere of Politics / Sfera Politicii, 25(1/2), 76-82. Retrieved from Walden Library databases.

5) BOWSTEAD, J. C. (2015). Why women's domestic violence refuges are not local services. Critical Social Policy, 35(3), 327-349. Retrieved from Walden Library databases.

6) Ćejvanović, F., Kovačević, A., Grgić, Z., Maksimović, A., \& Miletić, V. (2015). The Effect of Rural Development Policy on Domestic Violence. Economics of Agriculture / Ekonomika Poljoprivrede, 62(2), 543. Retrieved from Walden Library databases.

7) Cheluchi Onyemelukwe, author. (2018). How well does the law protect women at home? An analysis of Nigeria's domestic violence legislation. International Journal of Law and Management, (2), 186. Retrieved from Walden Library databases.

8) Domestic Sexual and Violence Response Team. (n.d.). Retrieved from https://www.dsvrtlagos.org/.

9) Fagan, A. (2017). Cultural Harm and Engaging the Limits of a Right to Cultural Identity. Human Rights Quarterly, 39(2), 319-340. Retrieved from Walden Library databases.

10) Fakunmoju, S. B., \& Rasool, S. (n.d.). Exposure to Violence and Beliefs About Violence Against Women Among Adolescents in Nigeria and South Africa. SAGE OPEN, 8(4). Retrieved from Walden Library databases.

11) Gage, A. J., \& Thomas, N. J. (2017). Women's Work, Gender Roles, and Intimate Partner Violence in Nigeria. Archives Of Sexual Behavior, 46(7), 1923-1938. Retrieved from Walden Library databases.

12) Helmersson, S., \& Jönson, H. (2015). The use of 'empowerment' among organizations supporting victims of domestic violence in Sweden. European Journal of Social Work, 18(1), 51-64. Retrieved from Walden Library databases.

13) Johnson, G. (2014). Research methods for public administrators (3rd ed.). Armonk, NY: M. E. Sharpe.

14) Khan, A. R. (2015). Consequences of Domestic Violence against Women: Some Reflections from Rural Bangladesh. Asian Social Work \& Policy Review, 9(3), 210223. Retrieved from Walden Library databases.

15) Kim, D. (2018). Marital rape immunity in India: historical anomaly or cultural defense? Crime, Law \& Social Change, 69(1), 91-107 Retrieved from Walden Library databases.

16) Leclerc, B., Chiu, Y.-N., Cale, J., \& Cook, A. (2016). Sexual Violence Against Women Through the Lens of Environmental Criminology: Toward the Accumulation of Evidence-based Knowledge and Crime Prevention. European Journal on Criminal Policy \& Research, 22(4), 593-617. Retrieved from Walden Library databases. 
17) Liao, Y., Carris, K., Leclere, F., \& Amaya, A. (2015). Where to start: an evaluation of primary data-collection modes in address-based sampling design. Public Opinion Quarterly, (2), 420. Retrieved from the Walden Library databases

18) Madu. J.C. (Sept.2015). Domestic violence legislation for development, peace, and security in Nigeria: African Security Review (24/3) 279-290. DOI: 10.1080/10246029.2015.1070274., Database: International Security \& Counter Terrorism Center.

19) Mary McCauley, Jennifer Head, Jaki Lambert, Shamsa Zafar, \& Nynke van den Broek. (2017). "Keeping family matters behind closed doors": healthcare providers' perceptions and experiences of identifying and managing domestic violence during and after pregnancy. BMC Pregnancy and Childbirth, Vol 17, Iss 1, Pp 1-8 (2017), (1), 1. Retrieved from Walden Library databases.

20) McQuigg, R. J. A. (2018). Is it time for a U.N. treaty on violence against women? International Journal of Human Rights, 22(3), 305-324. Retrieved from Walden Library databases.

21) Menjívar, C., \& Walsh, S. D. (2017). The Architecture of Feminicide: The State, Inequalities, and Everyday Gender Violence in Honduras. Latin American Research Review, 52(2), 221-240 Retrieved from Walden Library databases.

22) Metz, C., Calmet, J., \& Thevenot, A. (2018). Women subjected to domestic violence: The impossibility of separation. Psychoanalytic Psychology. Retrieved from Walden Library databases.

23) Nussbaum, M. C. (2016). Women's Progress and Women's Human Rights. Human Rights Quarterly, 38(3), 589-622. Retrieved from Walden Library databases.

24) Nwabunike. C., Tenkorang. Y. (2017). Domestic and marital violence among three ethnic groups in Nigeria: Journal of Interpersonal Violence (32/18). Sagepub.com/journalsPermissions.nav. DOI:10.1177/0886260515596147. Retrieved from Walden Library databases.

25) Odion, J., \& Eboigbe, E. (2018). Eliminating harmful practices against women in Nigeria: an examination of the Violence against Women Persons (Prohibition) Act, 2015. International Journal of Human Rights, 22(7), 933-945. Retrieved from Walden Library databases.

26) Pinheiro Rodrigues, N. C., O’Dwyer, G., de Noronha Andrade, M. K., Flynn, M. B., Maia Monteiro, D. L., \& Saraiva Lino, V. T. (2017). The increase in domestic violence in Brazil from 2009-2014. Revista Ciência \& Saúde Coletiva, 22(9), 2873-2880. https://doi-org.ezp.waldenulibrary.org/10.1590/1413-81232017229.09902016

27) Schoonenboom, J., \& Johnson, R. B. (2017). How to construct a mixed methods research design. Kölner Zeitschrift Für Soziologie Und Sozialpsychologie, 69(Suppl 2), 107-131. Retrieved from the Walden Library databases

28) Schouten, B. (2018). Statistical inference based on randomly generated auxiliary variables. Journal of the Royal Statistical Society: Series B (Statistical Methodology), 80(1), 33-56. Retrieved from the Walden Library databases.

29) Sherif, V. (2018). Evaluating Preexisting Qualitative Research Data for Secondary Analysis. Forum: Qualitative Social Research, 19(2), 26-42. Retrieved from the Walden Library databases 
30) Solanke, B. L., Bisiriyu, A. L., \& Oyedokun, A. (n.d.). Is the likelihood of spousal violence lower or higher among childless women? Evidence from Nigeria demographic and health surveys. BMC WOMEN'S HEALTH, 18. Retrieved from Walden Library databases.

31) Tabassum, N., Tabassum, H., \& Afzal, T. (2015). A Sociological Study of the Factors Affecting Crime against Women in Pakistan. Government: Research Journal of Political Science, 3, 15-28. Retrieved from Walden Library databases.

32) The Istanbul Convention and the Positive Obligation to Prevent Violence. Human Rights Law Review, 18(1), 133-155. Retrieved from Walden Library databases.

33) Thiel, S. V. (2014). Research in public administration and public management: An introduction. London: Routledge.

34) Tuija Virkki. (2017). At the Interface of National and Transnational: The Development of Finnish Policies against Domestic Violence in Terms of Gender Equality. Social Sciences, Vol 6, Iss 1, p 31 (2017), (1), 31. Retrieved from Walden Library databases.

35) Tunstall, A. M., Weible, C. M., Tomsich, E. A., \& Gover, A. R. (2016). Understanding Policy Reform in Colorado's Domestic Violence Offender Treatment Standards. Social Policy \& Administration, 50(5), 580-598. Retrieved from Walden Library databases.

36) Walden University. (n.d.). Vision and mission statements. Retrieved from http://www.waldenu.edu/about/who-we-are/data/vision-mission-statements

37) Zulfiqar, F. (2017). Issues on Explaining Legal Recognition of Marital Rape in Islam in Pakistan. International Journal of Interdisciplinary Civic \& Political Studies, 12(1), 1-12. Retrieved from Walden Library databases.

\section{Works Cited}

Oluwadele, L. Bolutife, Okaiyeto, Simon Ayodele Olaogun, Michael Sunkanmi. (2021). Appraisal of Public Perception of Lagos State Domestic Violence Policy. International Journal of Scientific and Management Research, 04(05), 151-165. doi: http://doi.org/10.37502/IJSMR.2021.4509 